\title{
PENDIDIKAN ISLAM PADA MASA DAULAH BANI UMAYYAH
}

\author{
Yusnadi $^{1}$, Fakhrurrazi $^{2}$ \\ ${ }^{1}$ Sekolah Tinggi Agama Islam Darul Hikmah Aceh Barat \\ ${ }^{2}$ Institut Agama Islam Negeri Langsa \\ Email: ${ }^{1}$ eqaratindo@yahoo.com; ${ }^{2}$ frazilgs@yahoo.com
}

\begin{abstract}
Abstrak
Sejarah pendidikan Islam pada hakekatnya sangat berkaitan erat dengan sejarah Islam. Periodesasi pendidikan Islam selalu berada dalam periode sejarah Islam itu sendiri. Pendidikan Islam di zaman Nabi Muhammad SAW merupakan periode pembinaan pendidikan Islam dengan cara membudayakan pendidikan Islam dalam kehidupan seharihari sesuai dengan ajaran Al-Qur'an. pendidikan pada periode Bani Umayyah telah berkembang jika dilihat dari aspek pengajarannya, walaupun sistemnya masih sama seperti pada masa Nabi dan khulafaur rasyidin.
\end{abstract}

Kata kunci: Pendidikan, Islam, Bani Umayyah.

\begin{abstract}
The history of Islamic education is in essence very closely related to the history of Islam. The period of Islamic education is always in the period of Islamic history itself. Islamic education at the time of the Prophet Muhammad SAW was a period of fostering Islamic education by cultivating Islamic education in everyday life in accordance with the teachings of the Qur'an. education in the period of the Umayyads had evolved when viewed from the aspect of its teaching, even though the system was still the same as in the time of the Prophet and the khulafaurrasyidin.
\end{abstract}

Keywords: Education, Islam, Bani Umayyah 


\section{A. PENDAHULUAN}

Pendidikan Islam merupakan suatu hal yang paling utama bagi warga suatu negara, karena maju dan keterbelakangan suatu negara akan ditentukan oleh tinggi dan rendahnya tingkat pendidikan warga negaranya. Salah satu bentuk pendidikan yang mengacu kepada pembangunan tersebut yaitu pendidikan agama adalah modal dasar yang merupakan tenaga penggerak yang tidak ternilai harganya bagi pengisian aspirasi bangsa, karena dengan terselenggaranya pendidikan agama secara baik akan membawa dampak terhadap pemahaman dan pengamalan ajaran agama.

Pendidikan Islam bersumber kepada Al-Qur'an dan Hadits adalah untuk membentuk manusia yang seutuhnya yakni manusia yang beriman dan bertaqwa terhadap Allah Swt, dan untuk memelihara nilai-nilai kehidupan sesama manusia agar dapat menjalankan seluruh kehidupannya, sebagaimana yang telah ditentukan Allah dan Rasul-Nya, demi kebahagiaan hidup di dunia dan akhirat. atau dengan kata lain, untuk mengembalikan manusia kepada fitrahnya yaitu memanusiakan manusia, supaya sesuai dengan kehendak Allah yang menciptakan sebagai hamba dan khalifah di muka bumi.

Sejarah pendidikan Islam pada hakekatnya sangat berkaitan erat dengan sejarah Islam. Periodesasi pendidikan Islam selalu berada dalam periode sejarah Islam itu sendiri. Secara garis besarnya Harun Nasution membagi sejarah Islam ke dalam tiga periode. Yaitu periode Klasik, Pertengahan dan Modern. Kemudian perinciannya dapat dibagi lima periode, yaitu: Periode Nabi Muhammad SAW (571-632 M), periode Khulafa ar Rasyidin (632-661 M), periode kekuasaan Daulah Bani Umayyah (661-750 M), periode kekuasaan Abbasiyah (750-1250 M) dan periode jatuhnya kekuasaan khalifah di Baghdad (1250-sekarang) (Zuhairini, 1992: 7).

Pendidikan Islam di zaman Nabi Muhammad SAW merupakan periode pembinaan pendidikan Islam, dengan cara membudayakan pendidikan Islam dalam kehidupan sehari-hari sesuai dengan ajaran Al-Qur'an. Setelah itu dilanjutkan pada periode Khulafar ar Rasyidin dan Bani Umayyah yang merupakan periode pertumbuhan dan perkembangan ilmu pengetahuaan yang ditandai dengan berkembangnya ilmu-ilmu Naqliah dan'Aqliah. Melalui artikel yang sederhana ini penulis mencoba untuk menggambarkan tentang pendidikan Islam pada masa Bani Umayyah.

\section{B. HASIL DAN PEMBAHASAN}

\section{Dinasti Umayyah}

Kekuasaan Bani Umayyah berumur kurang lebih 90 tahun. Ibu kota negara dipindahkan Muawiyyah dari Madinah ke Damaskus, tempat ia berkuasa sebagai gubernur sebelumnya. Muawwiyah Ibn Abi Sofyan adalah pendiri Dinasti Umayyah yang berasal dari suku Quraisy keturunan Bani Umayyah yang merupakan khalifah pertama dari tahun 661-750 M, nama lengkapnya ialah Muawwiyah bin Abi Harb bin Umayyah bin Abdi Syam bin Manaf (Dewan Redaksi, Ensiklopedi Islam, 1967: 14).

Setelah Muawwiyah diangkat jadi khalifah ia menukar system pemerintahan dari Theo Demikrasi menjadi Monarci (Kerajaan/Dinasti) dan sekaligus memindahkan Ibu Kota Negara dari Kota Madinah ke Kota Damaskus. Muawwiyah lahir 4 tahun menjelang Nabi Muhammad SAW menjalankan Dakwah Islam di Kota Makkah, ia beriman dalam usia muda dan ikut hijrah 
bersama Nabi ke Yastrib. Disamping itu termasuk salah seorang pencatat wahyu dan ambil bagian dalam beberapa peperangan bersama Nabi (Yusuf Syu'aib, 1997: 13).

Pada masa khalifah Abu Bakar Siddiq dan Kalifah Umar ibn Khattab, Umayyah menjabat sebagai panglima pasukan dibawah pimpinan Ubaidah ibn Jarrah untuk wilayah Palestina, Suriah dan Mesir. Pada masa khalifah Usman ibn Affan ia diangkat menjadi Wali untuk wilayah Suriah yang berkedudukan di Damaskus. Pada masa pemerintahan Ali ibn Abi Thalib tahun $661 \mathrm{M}$ diwarnai dengan krisis dan pertentangan yang sangat tajam di wilayah Islam dimana ditandai dengan perang Shuffin yang pada akhirnya Ali ibn Abi Thalib mati terbunuh sewaktu shalat shubuh di Mesjid Nabawi Madinah ((Yusuf Syu'aib, 1997: 14).

Sepeninggal Ali ibn Abi Thalib tahun $661 \mathrm{M}$ sebagian umat Islam di Iraq memilih dan mengangkat Hasan ibn Ali ibn Thalib menjadi Khalifah. Akan tetapi Hasan adalah orang yang taat, bersikap damai serta tidak tega dengan perpecahan dalam Islam. Akhirnya diadakanlah serah terima kekuasaan di Kota Khuffah. Dengan demikian dimulailah Dinasti Umayyah.

Bani Umayyah perluasan daerah Islam sangat luas sampai ke timur dan barat. Begitu juga dengan daerah Selatan yang merupakan tambahan dari Daerah Islam di zaman Khulafa ar Rasyidin yaitu: Hijaz, Syiria, Iraq, Persia dan Mesir.

Seiring dengan itu pendidikan pada masa Bani Umayyah telah ada beberapa lembaga seperti: Kutub, Mesjid dan Majelis Sastra. Materi yang diajarkan bertingkat-tingkat dan bermacam-macam. Metode pengajarannya pun tidak sama. Sehingga melahirkan beberapa pakar ilmuan dalam berbagai bidang tertentu (Hasan Langgulung, (Hasan Langgulung, 1980: 17).

\section{Pertumbuhan dan Perkembangan Pendidikan Islam Pada Masa Daulah Bani Umayyah}

Pertumbuhan dan perkembangan pendidikan Islam pada masa ini berjalan seperti di zaman permulaan Islam, hanya ada sedikit peningkatan sesuai dengan perkembangan Daulah Islamiyah sendiri. Sebagaimana telah diketahui bersama bahwa pertumbuhan dan perkembangan pendidikan Islam dibagi dalam 5 periode, sedangkan untuk pendidikan Islam bani Umayyah masuk dalam kategori periode 2, yaitu periode pertumbuhan pendidikan Islam yang berlangsung sejak Nabi Muhammad saw wafat sampai masa akhir bani Umayyah. Sehingga karena masih dalam masa pertumbuhan, maka hanya ada sedikit kemajuan seperti yang diterangkan di atas. Kamajuan ini hanya diwarnai dengan berkembangnya ilmu-ilmu Naqliyah yaitu filsafat dan ilmu eksakta disamping juga ilmu-ilmu agama yang sudah berkembang sebelumnya.

Faktor yang menyebabkan kurang pesatnya perkembangan ilmu-ilmu pada zaman ini salah satunya adalah faktor pemerintahan bani Umayyah yang lebih suka pada membangun kekuatan pemerintahan/politik yang cenderung otoriter.

Pada zaman Daulah Bani Umayyah ada tiga gerakan yang berkembang dengan sendirinya, yaitu 1) Gerakan Ilmu Agama, karena didorong semangat agama sendiri yang sangat kuat pada waktu itu, 2) Gerakan Filsafat, karena ahli agama di akhir bani Umayyah mempergunakan filsafat untuk melawan Yahudi dan Nasrani, DAN 3) Gerakan Sejarah, karena ilmui-ilmu agama memerlukan riwayat.

\section{a. Gerakan Ilmu Agama}

Gerakan di dalam bidang ini dapat di pisah-pisahkan menjadi beberapa bagian, yaitu: 
1) Lembaga dan pusat pendidikan Islam. Pada zaman ini masjid menjadi semacam lembaga sebagai pusat kehidupan dan kegiatan ilmu terutama ilmu-ilmu agama. Seorang ustadz duduk dalam masjid dan murid duduk di sekelilingnya mendengarkan pelajarannya. Kadang dalam satu masjid terdapat beberapa halaqah dengan ustadz dan pelajaran berbeda-beda. Kadang pula ustadz menggunakan rumahnya untuk mengajar. Pada zaman ini belum ada sekolah atau gedung khusus sebagai tempat belajar. Beberapa ustadz pada masa ini adalah Abdullah bin Abbas, Hasan Basri, Ja'far As-Shidiq dan lain-lain. Sedangkan kota-kota yang menjadi pusat kegiatan pendidikan ini masih seperti pada zaman Khulafaur rasyidin yaitu, Damaskus, Kufah, Basrah, Mesir dan ditambah lagi dengan pusat-pusat baru seperti Kordoba, Granada, Kairawan dan lain-lain.

2) Materi bidang ilmu pengetahuan. Materi/ilmu-ilmu agama yang berkembang pada zaman ini dapat dimasukan dalam kelompok Al-Ulumul Islamiyah yaitu ilmu-ilmu Al-Qur'an, Al-Hadits, Al-Fiqih, At-Tarikh, Al-Ulumul Lisaniyah dan Al-Jughrafi.

a) Ilmu Qiraat, yaitu ilmu cara membaca Al-Qur'an. Orang yang pandai membaca Al-Qur'an disebut Qurra. Pada zaman ini pula yang memunculkan tujuh macam bacaan Al-Qur'an yang terkenal dengan "Qiraat Tujuh" yang kemudian ditetapkan menjadi dasar bacaan (Ushulul Lil Qira'ah). Pelopor bacaan ini terdiri dari kaum Malawy yaitu antara lain : Abdulloh bin Katsir, Ashim bin Abu Nujud, Abdulloh bin Amir, Ali bin Hamzah dan lain-lain.

b) Ilmu Tafsir, ilmu yang berusaha untuk memberikan penafsiran terhadap ayatayat Al-Qur'an dengan tujuan untuk menghasilkan hukum dan undang-undang. Ahli tafsir yang pertama yaitu Ibnu Abbas, seorang shahabat terkenal yang wafat pada tahun $68 \mathrm{H}$. Menurut riwayat yang mutawatir beliau adalah orang yang pertama menafsirkan Al-Qur'an dengan cara riwayat dan isnad. Ahli tafsir lainnya adalah Mujahid yang wafat pada tahun $109 \mathrm{H}$ dan ulama Syi'ah yaitu Muhammad Al-Baqir bin Ali bin Husain.

c) Ilmu Hadits, Untuk membantu di dalam memahami ayat-ayat Al-Qur'an. Karena terdapat banyak hadits maka timbullah usaha untuk mencari riwayat dan sanad yang hadits yang akhirnya menjadi Ilmu Hadits dengan segala cabang-cabangnya. Para ahli hadits yang terkenal pada zaman ini adalah : Abu Bakar bin Muhammad bin Ubaidillah bin Zihab Az-Zuhri ( W. 123 H ). Ibnu Abi Malikiah, yaitu Abdulloh bin Abi Malikiah ( W. 119 H ). Pada masa kholifah Umar bin Abdul Aziz barulah hadits dibukukan yang dirintis oleh Ibnu Zihab Az-Zuhri yang kemudian disusul oleh ulama lain.

d) Ilmu Nahwu, yaitu ilmu tentang perubahan bunyi pada kata-kata yang terdapat di dalam Al-Qur'an.Pengarang ilmu nahwu yang pertama dan membukukannya seperti halnya sekarang, yaitu Abu Aswad Ad-Dualy ( W. 69 H ). Beliau belajar dari Ali bin Abi Thalib sehingga ada ahli sejarah yang mengatakan bahwa Ali bin Abi Thalib adalah Bapak Ilmu Nahwu.

e) Ilmu Jughrafi. Tentang ilmu jughrafi sekalipun bukan berasal dari bangsa arab, namun bangsa Arab muslim telah membuat ilmu ini menjadi satu ilmu yang tersendiri oleh karena tiga sebab : Al-Haj yang menjadi salah satu rukun Islam. 
Untuk menunaikan rukun haji kaum Muslimin di seluruh penjuru dunia harus mengetahui ilmu bumi.

f) Al-Ilmu. Kewajiban menuntut ilmu bagi kaum muslimin, mengharuskan mereka melakukan Rihlah Ilmiyah untuk menuntut ilmu, hal mana mengharuskan kaum muslimin mengetahui ilmu bumi.

g) Dakwah. Keharusan berdakwah dan berjihad untuk mengembangkan Islam, juga mengharuskan kaum muslimin mengetahui ilmu bumi.

Tiga sebab ini disamping sebab-sebab lain yang mendorong orang Yunani lama untuk membuat ilmu bumi yaitu kepentingan dagang dan perang. Ilmu Jughrofi dalam masa daulah bani Umayyah baru dalam taraf merintis jalan.

Sedangkan ilmu-ilmu yang di salin dari bahasa Asing ke dalam bahasa Arab dan di sempurnakan untuk kepentingan keilmuan umat Islam dikelompokan dalam Al-Ulumud Dakhilah yang terdiri dari:

1) Ilmu Kimia. Khalifah Yazid bin Yazid bin Mua'wiyah adalah yang menyuruh penerjemahannya ke dalam bahsa Arab.Beliau mendatangkan beberapa orang Romawi yang bermukim di Mesir, di antaranya Maryanis seorang pendeta yang mengajarkan ilmu kimia. Penerjemahan ke dalam bahasa Arab dilakukan oleh Isthafun.

2) Ilmu Bintang. Masih dalam masa Kholid bin Walid, beliau sangat menggemari ilmu ini sehingga dikeluarkan sejumlah uang untuk mempelajari dan membeli alat-alatnya. Karena gemarnya setiap akan pergi ke medan perang selalu dibawanya ahli ilmu bintang.

3) Ilmu Kedokteran. Penduduk Syam di jaman ini telah banyak menyalin bermacam ilmu ke dalam bahasa Arab seperti ilmu-ilmu kedokteran, mislanya karanganm Qis Ahrun dalam bahasa Suryani yang disalin ke dalam bahasa Arab oleh Masajuwaihi.

\section{b. Gerakan Filsafat}

Gerakan filsafat muncul di akhir zaman daulah bani Umayyah untuk melawan pemikiran Yahudi dan Nasrani. Pemikiran teologis dari agama Kristen sudah berkembang lebih dulu sebelum datangnya Islam dan masuk ke lingkungan Islam secara sengaja untuk merusak akidah Islam. Karena itu timbul dalam Islam pemikiran yang bersifat teologis untuk menolak ajaranajaran teologis dari agama Kristen yang kemudian disebut Ilmu Kalam. Ilmu kalam dalam perkembangannya menjadi ilmu khusus yang membahas tentang berbagai macam pola pemikiran yang berbeda dari ajaran Islam sendiri, karena dalam Al-Qur'an terdapat banyak ayat yang memerintahkan untuk membaca, berfikir, menggunakan akal dan sebagainya yang kesemuanya mendorong umat Islam, terutama para ahlinya untuk berfikir mengenai segala sesuatu guna mendapatkan kebenaran dan kebijaksnaan.

\section{c. Gerakan Sejarah}

Pada zaman bani Umayyah gerakan sejarah menghasilkan tarikh yang terbagi dalam dua bidang besar :

1) Tarikh Islam, yaitu tarikh kaum muslimin dengan segala perjuangannya, riwayat hidup pemimpin-pemimpin mereka. Sumber tarikh dalam bidang ini adalah dari amal perbuatan mereka sendiri. 
2) Tarikh umum, yaitu tarikh bangsa-bangsa lain yang dipelajari dan disalin dengan sungguh-sungguh sejan zaman bani Umayyah. Hal ini karena kholifah mereka termasuk orang-orang yang paling gemar untuk mengetahui orang-orang ternama dari tarikh bangsa lain. Pembukuan ilmu sejarah sudah dimulai dan berkembang pesat pada zaman Abbasiyah. Demikian pesatnya sehingga mencapai jumlah 1:300 judul seperti yang diterangkan dalam kitab Kashfud Dhunun

\section{Pola Pendidikan Islam Pada Masa Bani Umayyah}

Pola pendidikan pada periode Bani Umayyah telah berkembang jika dilihat dari aspek pengajarannya, walaupun sistemnya masih sama seperti pada masa Nabi dan khulafaur rasyidin. Pada masa ini peradaban Islam sudah bersifat internasional yang meliputi tiga benua, yaitu sebagian Eropa, sebagian Afrika dan sebagian besar Asia yang kesemuanya itu dipersatukan dengan bahasa Arab sebagai bahasa resmi Negara.

Pendidikan Islam pada masa Bani Umayyah telah berkembang bila dibandingkan pada masa Khulafa ar Rasyidin yang ditandai dengan semaraknya kegiatan ilmiah di mesjid-mesjid dan berkembangnya Khuttab serta Majelis Sastra. Jadi tempat pendidikan pada masa Bani Umayyah adalah:

\section{a. Khuttab}

Khuttab atau Maktab berasaal dari kata dasar kataba yang berarti menulis atau tempat menulis, jadi Khuttab adalah tempat belajar menulis. Khuttab merupakan tempat anak-anak belajar menulis dan membaca, menghafal Al Quran serta belajar pokok-pokok ajaran Islam (Mahmud. Yunus, 1981: 39).

Adapun cara yang dilakukan oleh pendidik disamping mengajarkan Al Quran mereka juga belajar menulis dan tata bahasa serta tulisan. Perhatian mereka bukan tertumpu mengajarkan Al Quran semata dengan mengabaikan pelajaran yang lain, akan tetapi perhatian mereka pada pelajaran sangat pesat. Al Quran dipakai sebagai bahasa bacaan untuk belajar membaca, kemudian dipilih ayat-ayat yang akan ditulis untuk dipelajari. Disamping belajar menulis dan membaca murid-murid juga mempelajari tatabahasa Arab, cerita-cerita Nabi, hadist dan pokok agama (Zuhairini, 1992: 47).

Kalau dilihat di dalam sejarah pendidikan Islam pada awalnya dikenal dua bentuk Kuttab, yaitu:

1) Kuttab berfungsi sebagai tempat pendidikan yang memfokuskan pada tulis baca (Samsul Nizar, 2005: 7).

2) Kuttab tempat pendidikan yang mengajarkan Al Quran dan dasar-dasar keagamaan(Samsul Nizar, 2005: 8).

Peserta didik dalam Khutab adalah anak-anak, tidak dibatasi baik miskin ataupun kaya. Para guru tidak membedakan murid-murid mereka, bahkan ada sebagian anak miskin yang belajar di Khuttab memperoleh pakaian dan makanan secara cuma-cuma. Anak-anak perempuan pun memperoleh hak yang sama dengan anak-anak laki-laki dalam belajar (Athiyya Al Abrasi, 1993: 15). Namun tidak tertutup kemungkinan bagi orang yang mampu mendidik anak-anak mereka di tempat khusus yang mereka inginkan dengan guru-guru yang khusus pula seperti: Hajjad ibn Yusuf yang pernah menjadi guru bagi putra Sulaiman Nasuh seorang Menteri dari khalifah Abdul Malik ibn Marwan (Asma Hasan Fahmi, tth: 47). 


\section{b. Mesjid}

Setelah pelajaran anak-anak di khutab selesai mereka melanjutkan pendidikan ke tingkat menengah yang dilakukan di mesjid. Peranan Mesjid sebagai pusat pendidikan dan pengajaran senantiasa terbuka lebar bagi setiap orang yang merasa dirinya tetap dan mampu untuk memberikan atau mengajarkan ilmunya kepada orang-orang yang haus akan ilmu pengetahuan.

Pada Bani Umayyah, Mesjid merupakan tempat pendidikan tingkat menengah dan tingkat tinggi setelah khuttab. Pelajaran yang diajarkan meliputi Al Quran, Tafsir, Hadist dan Fiqh. Juga diajarkan kesusasteraan, sajak, gramatika bahasa, ilmu hitung dan ilmu perbintangan (Athiyya $\mathrm{Al}$ Abrasi, 1993: 56).

Diantara jasa besar pada masa Bani Umayyah dalam perkembangan ilmu pengetahuan adalah menjadikan Mesjid sebagai pusat aktifitas ilmiah termasuk sya'ir. Sejarah bangsa terdahulu diskusi dan akidah. Pada periode ini juga didirikan Mesjid ke seluruh pelosok daerah Islam. Mesjid Nabawi di Madinah dan Masjidil Haram di Makkah selalu menjadi tumpuan penuntut ilmu diseluruh dunia Islam dan tampak juga pada pemerinath Walid ibn Abdul Malik 707-714 M yang merupakan Universitas terbesar dan juga didirikan Mesjid Zaitunnah di Tunisia yang dianggap Universitas tertua sampai sekarang (Hasan Langgulung, 1980: 19).

Pada Bani Umayyah ini, mesjid sebagai tempat pendidikan terdiri dari dua tingkat yaitu: tingkat menengah dan tingkat tinggi. Pada tingkat menengah guru belumlah ulama besar sedangkan pada tingkat tinggi gurunya adalah ulama yang dalam ilmunya dan masyhur kealiman dan keahliannya. Umumnya pelajaran yang diberikan guru kepada murid-murid seorang demi seorang, baik di Khuttab atau di Mesjid tingkat menengah. Sedangkan pada tingkat pelajaran yang diberikan oleh guru adalah dalam satu Halaqah yang dihadiri oleh pelajar bersama-sama.

\section{c. Majelis Sastra}

Majelis sastra merupakan balai pertemuan yang disiapkan oleh khalifah dihiasi dengan hiasan yang indah, hanya diperuntukkan bagi sastrawan dan ulama terkemuka. Menurut M. Al Athiyyah Al Abrasy "Balai-balai pertemuan tersebut mempunyai tradisi khusus yang mesti diindahkan seseorang yang masuk ketika khalifah hadir, mestilah berpakaian necis bersih dan rapi, duduk di tempat yang sepantasnya, tidak tertawa terbahak-bahak, tidak meludah, tidak mengingus dan tidak menjawab kecuali bila ditanya. Ia tidak boleh bersuara keras dan harus bertutur kata dengan sopan dan memberi kesempatan pada sipembicara menjelaskan pembicaraannya serta menghindari penggunaan kata kasar dan tawa terbahak-bahak. Dalam balai-balai pertemuan seperti ini disediakan pokok-pokok persoalan untuk dibicarakan, didiskusikan dan diperdebatkan" (Athiyya Al Abrasi, 1993: 6).

Hal diatas sesuai dengan wasiat Abdul Malik ibn Harman kepada pendidik puteranya dengan pesan "Ajarkan kepada mereka berkata benar disamping mengajarkan Al Quran. Jauhkanlah mereka dari orang-orang jahat yang tidak mengindahkan perintah Allah dan tidak berlaku sopan, dan jauhkan juga mereka chadam dan pekerjaannya karena bergaul dengan mereka akan dapat merusak moralnya. Gunakanlah perasaan mereka agar badannya kuat, dan serahkanlah mereka bersufi dan air dengan menghisabnya pelan-pelan dan jangan minum tidak senonoh bila memerlukan teguran hendaklah secara tertutup, jangan sampai diketahui oleh pelayan dan tamu agar mereka tidak dipandang rendah (Ahmad Salabi, 1972: 49). 
Majelis sastra merupakan tempat berdiskusi membahas masalah kesusasteraan dan juga sebagai tempat berdiskusi mengenai urusan politik. Perhatian penguasa Ummayyah sangat besar pada pencatatan kaidah-kaidah nahwu, pemakaian Bahasa Arab dan mengumpulkan Syair-syair Arab dalam bidang syariah, kitabah dan berkembangnya semi prosa(Ahmad Salabi, 1972: 72).

Usaha yang tidak kalah pentingnya pada masa Bani Umayyah ini dimulainya penterjemahan ilmu-ilmu dari bahasa lain ke dalam Bahasa Arab, seperti yang dilakukan oleh Khalid ibn Yazid ia memerintahkan beberapa sarjana Yunani da Qibti ke dalam Bahasa Arab tentang ilmu Kimia, Kedokteran dan Ilmu Falaq (Ahmad Salabi, 1972: 19).

Pada Masa Bani Umayyah ini terkenal sibuk dengan pemberontakan dalam negeri dan sekaligus memperluas daerah kerajaan tidak terlalu banyak memusatkan perhatian pada perkembangan ilmiah, akan tetapi muncul beberapa ilmuwan terkemuka dalam berbagai cabang ilmu seperti yang dikemukana oleh Abd. Malik Ibn Juraid al Maki dan cerita peperangan serta syair dan Kitabah (Hasan Langgulung, 1980: 18-19).

Ilmu tafsir memiliki makna yang strategis, disamping karena faktor luasnya kawasan Islam ke beberapa daerah luar Arab yang membawa konsekwensi lemahnya rasa seni sastra arab, juga karena banyaknya yang masuk Islam. Hal ini menyebabkan pencemaran bahasa Al Quran dan makna Al Quran yang digunakan untuk kepentingan golongan tertentu. Pencemaran Al Quran juga disebabkan oleh faktor intervensi yang didasarkan kepada kisah-kisah Israiliyyat. Tokohnya adalah Abd Malik ibn Juraid al Maki. Selain ilmu tafsir ilmu hadist juga mendapatkan perhatian serius. Pentingnya periwayatan hadist sehingga dapat dipertanggung jawabkan secara ilmiah maupun secara moral. Namun keberhasilan yang diraihnya adalah semangat untuk mencari hadist, sebelum mencapai tahap kodifikasi. Khalifah Umar ibn Abdul Aziz yang memerintah hanya dua tahun 717-720 M pernah mengirim surat kepada Abu Bakar ibn Amir bin Ham dan kepada ulama yang lain untuk menuliskan dan mengumpulkan hadist-hadist, namun hingga akhir pemerintahannya hal itu tidak terlaksana. Sungguhpun demikian pemerintahannya hal itu tidak terlaksana. Sungguhpun demikian pemerintahan Umar ibn Aziz telah melahirkan metode pendidikan alternative, yakni para ulama mencari hadist ke berbagai tempat dan orang yang dianggap mengetahuinya yang kemudian dikenal metode Rihlah.

Dibidang fiqh secara garis besarnya dapat dibedakan menjadi dua kelompok yaitu aliran ahli al-Ra'y dan aliran al hadist, kelompok aliran pertama ini mengembangkan hukum Islam dengan menggunakan analogi atau Qiyas, sedangkan aliran yang kedua lebih berpegang pada dalil-dalil, bahkan aliran ini tidak akan memberikan fatwa jika tidak ada ayat Al Quran dan hadits yang menerangkannya. Nampaknya disiplin ilmu fiqh menunjukkan perkembangan yang sangat berarti. Masa ini telah melahirkan sejumlah mujtahid fiqh. Terbukti ketika akhir masa Umayyah telah lahir tokoh mazhab yakni Imam Abu Hanifah di Irak dan Imam Malik Ibn Anas di Madinah, sedangkan Imam Syafi'i dan Imam Ahmad ibn Hanbal lahir pada masa Abbasyiyah (Munawar Chalil, 1989: 23).

Di bidang syair yang terkenal dikalangan orang Arab diantaranya adalah tentang pujian, sebagaimana syair berikut yang artinya: "Engkau adalah pengendara kuda yang paling baik, engkau adalah orang yang pemurah di atas dunia ini"

Pada masa Bani Umayyah pada bidang pendidikan, adalah menekankan ciri ilmiah pada Mesjid sehingga menjadi pusat perkembangan ilmu pengetahuan tinggi dalam masyarakat Islam. Dengan penekanan ini di Mesjid diajarkan beberapa macam ilmu, diantaranya syair, sastra dan 
ilmu lainnya. Dengan demikian periode antara permulaan abad ke dua hijrah sampai akhir abad ketiga hijrah merupakan zaman pendidikan Mesjid yang paling cemerlang.

Nampaknya pendidikan Islam pada masa Bani Umayyah ini hampir sama dengan pendidikan pada masa Khulafa ar Rasyiddin. Hanya saja memang ada sisi perbedaan perkembangannya. Perhatian para Khulafa dibidang pendidikan agaknya kurang memperhatikan perkembangannya sehingga kurang maksimal, pendidikan berjalan tidak diatur oleh pemerintah, tetapi oleh para ulama yang memiliki pengetahuan yang mendalam. Kebijakan-kebijakan pendidikan yang dikeluarkan oleh pemerintah hampir tidak ditemukan. Jadi sistem pendidikan Islam ketika itu masih berjalan secara alamiah karena kondisi ketika itu diwarnai oleh kepentingan politis dan golonga.

Walaupun demikian pada periode Bani Umayyah ini dapat disaksikan adanya gerakan penerjemahan ilmu-ilmu dari bahasa lain ke dalam bahasa Arab, tetapi penerjemahan itu terbatas pada ilmu-ilmu yang mempunyai kepentingan praktis, seperti ilmu kimia, kedokteran, ilmu tata laksana dan seni bangunan. Pada umumnya gerakan penerjemahan ini terbatas keadaan orangorang tertentu dan atas usaha sendiri, bukan atas dorongan negara dan tidak dilembagakan. Menurut Franz Rosenthal orang yang pertama kali melakukan penerjemahan ini adalah Khalid ibn Yazid cucu dari Muawwiyah (Suwedi, 2004: 16).

\section{Tokoh - Tokoh Pendidikan Pada Masa Bani Umayyah}

Tokoh-tokoh pendidikan pada masa Bani Umayyah terdiri dari ulama-ulama yang menguasai bidangnya masing-masing seperti dalam bidang tafsir, hadist, dan Fiqh. Selain para ulama juga ada ahli bahasa/sastra.

Ulama-ulama tabi'in ahli tafsir, yaitu: Mujahid, 'Athak bin Abu Rabah, 'Ikrimah, Sa'id bin Jubair, Masruq bin Al-Ajda', Qatadah. Pada masa tabi' in tafsir Al-Qur'an bertambah luas dengan memasukkan Israiliyat dan Nasraniyat, karena banyak orang-orang Yahudi dan Nasrani memeluk agama Islam. Di antara mereka yang termasyhur: Ka'bul Ahbar, Wahab bin Munabbih, Abdullah bin Salam, Ibnu Juraij.

Ulama-ulama Hadist: Kitab bacaan satu-satunya ialah al-Qur'an. Sedangkan hadis-hadis belumlah dibukukan, Hadis-hadis hanya diriwayatkan dari mulut ke mulut. Dari mulut guru ke mulut muridnya, yaitu dari hafalan guru diberikannya kepada murid, sehingga menjadi hafalan murid pula dan begitulah seterusnya. Setengah sahabat dan pelajar-pelajar ada yang mencatat hadist-hadist itu dalam buku catatannya, tetapi belumlah berupa buku menurut istilah kita sekarang.

Ulama-ulama sahabat yang banyak meriwayatkan hadis-hadis ialah: Abu Hurairah (5374 hadist), 'Aisyah (2210 hadist), Abdullah bin Umar ( \pm 2210 hadist), Abdullah bin Abbas ( \pm 1500 hadist), Jabir bin Abdullah ( \pm 1500 hadist), Anas bin Malik ( \pm 2210 hadist).

Ulama-ulama ahli Fiqh: Ulama-ulama tabi'in Fiqih pada masa bani Umayyah diantaranya adalah: Syuriah bin Al-Harits, 'alqamah bin Qais, Masuruq Al-Ajda', Al-Aswad bin Yazid Kemudian diikuti oleh murid-murid mereka, yaitu: Ibrahim An-Nakh'i (wafat tahun $95 \mathrm{H}$ ) dan 'Amir bin Syurahbil As Sya'by (wafat tahun $104 \mathrm{H}$ ). Sesudah itu digantikan oleh Hammad bin Abu Sulaiman (wafat tahubn $120 \mathrm{H}$ ), guru dari Abu Hanafiah. Ahli bahasa/sastra: Seorang ahli bahasa seperti Sibawaih yang karya tulisnya Al-Kitab, menjadi pegangan dalam soal berbahasa arab. Sejalan dengan itu, perhatian pada syair Arab jahiliah pun muncul kembali sehingga bidang 
sastra arab mengalami kemajuan. Di zaman ini muncul penyair-penyair seperti Umar bin Abu Rabiah (w.719), Jamil al-uzri (w.701), Qys bin Mulawwah (w.699) yang dikenal dengan nama Laila Majnun, Al-Farazdaq (w.732), Jarir (w.792), dan Al akhtal (w.710). sebegitu jauh kelihatannya kemajuan yang dicapai Bani Umayyah terpusat pada bidang ekspansi wilayah, bahasa dan sastra arab, serta pembangunan fisik. Sesungguhnya dimasa ini gerakan-gerakan ilmiah telah berkembang pula, seperti dalam bidang keagamaan, sejarah dan filsafat. Dalam bidang yang pertama umpamanya dijumpai ulama-ulama seperti Hasan al-Basri, Ibnu Syihab Az-Zuhri, dan Wasil bin Ata. Pusat kegiatan ilmiah ini adalah Kufah dan Basrah di Irak. Khalid bin Yazid bin Mu'awiyah (w. 79/04/709) adalah seorang orator dan penyair yang berpikir tajam. Ia adalah orang pertama yang menerjemahkan buku-buku tentang astronomi, kedokteran, dan kimia.

\section{KESIMPULAN}

Pendidikan Islam merupakan suatu hal yang paling utama bagi warga suatu negara, karena maju dan keterbelakangan suatu negara akan ditentukan oleh tinggi dan rendahnya tingkat pendidikan warga negaranya. Kekuasaan Bani Umayyah berumur kurang lebih 90 tahun. Ibu kota negara dipindahkan Muawiyyah dari Madinah ke Damaskus, tempat ia berkuasa sebagai gubernur sebelumnya. Muawwiyah Ibn Abi Sofyan adalah pendiri Dinasti Umayyah yang berasal dari suku Quraisy keturunan Bani Umayyah yang merupakan khalifah pertama dari tahun 661-750 M, nama lengkapnya ialah Muawwiyah bin Abi Harb bin Umayyah bin Abdi Syam bin Manaf. Pertumbuhan dan perkembangan pendidikan Islam pada masa ini berjalan seperti di zaman permulaan Islam, hanya ada sedikit peningkatan sesuai dengan perkembangan Daulah Islamiyah sendiri.

Pola pendidikan pada masa Bani Umayyah melanjutkan pendidikan semasa Khulafa ar Rasyiddin, walaupun ada sisi perbedaan dan perkembangan tersendiri. Perkembangan tempattempat perkembangan pendidikan Islam pada masa Bani Umayyah ada tiga macam yaitu: 1) Kuttub, 2) Mesjid, 3) Masjelis Sastra. Disamping itu, pada Masa Bani Umayyah juga telah melaksanakan pendidikan dengan tingkat-tingkat sebagai berikut:1) Tingkat pertama, 2) Tingkat menengah, 3) Tingkat tinggi, di mana kurikulumnya telah disesuaikan dengan tingkatannya masing-masing.

Walaupun demikian pada periode Bani Umayyah ini dapat disaksikan adanya gerakan penerjemahan ilmu-ilmu dari bahasa lain ke dalam bahasa Arab, tetapi penerjemahan itu terbatas pada ilmu-ilmu yang mempunyai kepentingan praktis, seperti ilmu kimia, kedokteran, ilmu tata laksana dan seni bangunan. Pada umumnya gerakan penerjemahan ini terbatas keadaan orangorang tertentu dan atas usaha sendiri, bukan atas dorongan negara dan tidak dilembagakan. 


\section{DAFTAR PUSTAKA}

Al-Abrasyi, Athiyyah. (1993). al-Tarbiyyah al-Islamiyah, Terj. Bustami A. Gani, Jakarta: Bulan Bintang.

Chalil, Munawar. (1989). Empat Biografi Imam Mazhab, Jakarta: Bulan Bintang.

Dewan Redaksi. (1997). Ensiklopedi Islam, Jakarta : Ikhtiar Baru Van Hoeve.

Fakhrurrazi, F. (2016). Penerapan Metode Card Sort Dalam Peningkatan Motivasi Dan Kemampuan Belajar Siswa Bidang Studi Al-Qur'an Hadits, Al-Ikhtibar: Jurnal Pendidikan Agama Islam, 3 (2), 87-101. -, (2018). Hakikat Pembelajaran Yang Efektif, At-Tafkir, 11 (1), 85-99.

, (2018). Potret Pendidikan Keluarga Dalam Alquran (Tela'ah Q.S. At-Tahrim [66]: 6), At-Tibyan , 3(2), 188-199.

, (2019). Proceeding of International Conference on Islamic Educational Management, The Educator Creativity For Learning Managements, 149-157

Hasan, Fahmi Asma. (2000). Mabadi'at Tarbiyah al-Islamiyah, diterj. Oleh Mukhtar Yahya dan Sanusi Latif, Jakarta : Bulan Bintang.

Langgulung, Hasan. (1980). Pendidikan Islam Menghadapi Abad 21, Jakarta : Pustaka al-Husna. Nizar, Samsul. (2005). Sejarah Pergolakan Pemikiran Pendidikan Islam, Ciputat Press Group. Shalabi, Ahmad. (1972). Sejarah Pendidikan Islam, Jakarta : Bulan Bintang. Suaib, Yusuf. (1997). Sejarah Daulah Umayyah I, Jakarta : Bulan Bintang. Suwedi. (2004). Sejarah dan Pemikiran Pendidikan Islam, Jakarta : Raja Grafindo Persada. Yunus, Mahmud. (1981). Pendidikan Islam, Jakarta : Hidakarya Agung. Zuhairini. (1992). Sejarah Pendidikan Islam, Jakarta : Bumi Aksara. 